\title{
A Highly Selective Turn-on Fluorescent Probe for the Detection of Aluminum and Its Application to Bio-Imaging
}

\author{
Liguo Wang ${ }^{1}{ }^{\circledR}$, Jing Yang ${ }^{2, *}$, Huan Wang ${ }^{2}$, Chongzhao Ran ${ }^{2}$, Ying Su ${ }^{1} \mathbb{D}$ and Long Zhao ${ }^{1,3, *}$ \\ 1 Institute of Evolution and Marine Biodiversity, Ocean University of China, Qingdao 266003, China; \\ wlg159543@163.com (L.W.); suying@ouc.edu.cn (Y.S.) \\ 2 Athinoula A. Martinos Center for Biomedical Imaging, Massachusetts General Hospital and Harvard \\ Medical School, Boston, MA 02129, USA; hwang59@mgh.harvard.edu (H.W.); \\ cran@nmr.mgh.harvard.edu (C.R.) \\ 3 Cardiovascular Research Center, Massachusetts General Hospital and Harvard Medical School, Boston, \\ MA 02129, USA \\ * Correspondence: jyang37@mgh.harvard.edu (J.Y.); longzhao95@gmail.com (L.Z.)
}

Received: 29 April 2019; Accepted: 24 May 2019; Published: 28 May 2019

\begin{abstract}
Aluminum is the most abundant metallic element in the Earth's crust and acts as a non-essential element for biological species. The accumulation of excessive amounts of aluminum can be harmful to biological species. Thus, the development of convenient and selective tools for the aluminum detection is necessary. In this work, a highly selective aluminum ion fluorescent probe $\mathrm{N}^{\prime}$-(2,5-dihydroxybenzylidene)acetohydrazide (Al-II) has been successfully synthesized and systemically characterized. The fluorescence intensity of this probe shows a significant enhancement in the presence of $\mathrm{Al}^{3+}$, which is subject to the strong quench effects caused by $\mathrm{Cu}^{2+}$ and $\mathrm{Fe}^{3+}$. The binding ratio of probe- $\mathrm{Al}^{3+}$ was determined from the Job's plot to be 1:1. Moreover, the probe was demonstrated to be effective for in vivo imaging of the intracellular aluminum ion in both living Drosophila S2 cells and Malpighian tubules.
\end{abstract}

Keywords: aluminum; fluorescent probe; bio-imaging

\section{Introduction}

Aluminum is the most abundant metallic element in the Earth's crust. It can be found in a wide range of plants, drinking water, and food. It is also commonly used as metallic materials in the industrial and medical fields [1-3]. However, aluminum is a non-essential element for the human body. The accumulation of excessive amounts of aluminum can be harmful to human bodies, causing many medical problems and illnesses, including neurodegenerative and neurological disorders, such as Alzheimer's disease or Parkinson's disease [3-7].

Compared with other transition metal ions, the detection of aluminum has always been challenged by its poor coordination ability, strong hydration tendency, and the lack of spectroscopic characteristics [8]. Therefore, it is urgent to develop the convenient and selective methods for the detection of aluminum. Fluorescent approach is the most attractive and highly sensitive method to detect low concentrations of analysts [9]. In recent years, there has been considerable progress for the detection of aluminum utilizing fluorescent chemo-sensors [10-15]. However, there are still many limitations during the application of most reported fluorescent probes, such as working well only in anhydrous systems, poor selectivity or sensitivity, and weak binding ability [13,16-19]. Especially, the chemo-sensors for biological system are rare, most of which were applied in in vitro cultured cells, but not the living organisms. We summarized the reported Al probes suitable for bio-imaging in Table 1. 
Table 1. Summary of the fluorescent probes for aluminum in biological systems.

\begin{tabular}{ccc}
\hline Mechanism & Application & Reference \\
\hline FRET & Cultured Cell & {$[20]$} \\
PET & Cultured Cell & {$[21-23]$} \\
CHEF & Cultured Cell & {$[23,24]$} \\
AIEE & Cultured Cell & {$[25]$} \\
ESIPT & Cultured Cell & {$[23,26-28]$} \\
ESIPT & Bacteria (E. coli) & {$[12]$} \\
ESIPT & Plant (rice seedlings) & {$[29]$} \\
ESIPT & Cultured Cell and zebrafish & {$[13,30]$} \\
ESIPT & Cultured Cell and Drosophila & Present work \\
\hline
\end{tabular}

In this work, we synthesized a highly selective turn-on fluorescent probe $\mathrm{N}^{\prime}$-(2,5-dihydroxybenzylidene)acetohydrazide (Al-II) for $\mathrm{Al}^{3+}$ detection, which worked well in aqueous systems. Moreover, we successfully applied this probe to monitor the in vivo distribution of $\mathrm{Al}^{3+}$ either in living cultured Drosophila cells or organs, which provides a useful tool to selectively detect aluminum not only in inorganic systems but also in biological systems.

\section{Materials and Methods}

\subsection{HPLC Methods}

Liquid chromatography-mass spectrometry (LC-MS) was performed using an Agilent 1200 Series apparatus with an LC/MSD trap and Daly conversion dynode detector with UV detection at $254 \mathrm{~nm}$. The reverse phase high pressure liquid chromotragphy (RP-HPLC) method used in compound characterization is as follows: (A) Luna C18 column $(100 \times 2 \mathrm{~mm})$; eluent $\mathrm{A}: \mathrm{H}_{2} \mathrm{O} / 0.1 \%$ formic acid, $\mathrm{B}$ : $\mathrm{MeCN} / 0.1 \%$ formic acid; gradient: $5 \%$ B to $95 \%$ B over $3 \mathrm{~min}, 95 \%$ B for $1.5 \mathrm{~min}, 95 \%$ B to $5 \%$ B for $0.5 \mathrm{~min}$, then $5 \%$ B for $2 \mathrm{~min}$; flow rate $0.7 \mathrm{~mL} / \mathrm{min}$. (B) Luna C18 column $(100 \times 2 \mathrm{~mm})$; eluent $\mathrm{C}$ : $10 \mathrm{mM}$ ammonium acetate, D: $90 \% \mathrm{MeCN} / 10 \% 10 \mathrm{mM}$ ammonium acetate; gradient $5 \% \mathrm{D}$ for $0-1 \mathrm{~min}$, 5 to $95 \%$ D from $1-11 \mathrm{~min}, 95 \% \mathrm{D}$ from $11-12 \mathrm{~min}, 95 \%$ to $5 \% \mathrm{D}$ from $12-13 \mathrm{~min}, 5 \% \mathrm{D}$ from $13-15 \mathrm{~min}$; flow rate $0.7 \mathrm{~mL} / \mathrm{min}$.

\subsection{Synthesis of the Probe}

$\mathrm{N}^{\prime}$-(2,5-dihydroxybenzylidene)acetohydrazide was prepared by the refluxing acetic hydrazide $(0.37 \mathrm{~g}, 5.0 \mathrm{mmol})$ with salicylaldehyde $(0.69 \mathrm{~g}, 5.0 \mathrm{mmol})$ in $50 \mathrm{~mL}$ methanol for $3 \mathrm{~h}$. The solution was concentrated under reduced pressure, and the residue was further purified by recrystallization from methanol to afford $0.87 \mathrm{~g}(90 \%)$ as light green crystals.

LC-MS (method B): $\mathrm{t}_{\mathrm{R}}=4.462 \mathrm{~min}, \mathrm{~m} / \mathrm{z}=195.0[\mathrm{M}+\mathrm{H}]^{+}$(Figure S1).

${ }^{1} \mathrm{H}$ NMR (major:minor isomer = 1:0.88) $\left(500 \mathrm{MHz},\left(\mathrm{CD}_{3}\right)_{2} \mathrm{SO}\right) \delta 11.49(\mathrm{~s}, 1 \mathrm{H}$, major), $11.16(\mathrm{~s}, 1 \mathrm{H}$, minor), $10.29(\mathrm{~s}, 1 \mathrm{H}$, major), $9.39(\mathrm{~s}, 1 \mathrm{H}$, minor), $8.94(\mathrm{~s}, 1 \mathrm{H}$, major $), 8.88(\mathrm{~s}, 1 \mathrm{H}$, minor $), 8.24(\mathrm{~s}, 1 \mathrm{H}$, major), 8.19 (s, 1H, minor), $7.03(\mathrm{~d}, \mathrm{~J}=3.0 \mathrm{~Hz}, 1 \mathrm{H}$, minor), 6.91 (d, J = 2.6 Hz, 1H, major), 6.74-6.61 (m, $4 \mathrm{H}, 2$ from major, 2 from minor), 2.16 (s, 3H, minor), 1.95 (s, 3H, major) (Figure S2).

${ }^{13} \mathrm{C}$ NMR $\left(126 \mathrm{MHz},\left(\mathrm{CD}_{3}\right) 2 \mathrm{SO}\right) \delta 171.45,165.28,150.00,149.92,149.80,149.26,145.55,140.61$, $120.29,118.92,118.61,118.39,116.93,113.81,111.39,21.40,20.30$ (Figure S3).

\subsection{Compound Stock and Storage}

The Al-II probe powder was kept at $4{ }^{\circ} \mathrm{C}$ for long-term storage. The probe was dissolved into dimethyl sulfoxide (DMSO) to make a $10 \mathrm{mM}$ stock solution, which was stored at $4{ }^{\circ} \mathrm{C}$ for temporary preservation. 


\subsection{Drosophila S2 Cell Culture and Experiments}

Drosophila embryonic S2 cells were cultured with Gibco Schneider's Drosophila Medium (Invitrogen) containing $10 \%$ fetal bovine serum and penicillin $(50 \mathrm{IU} / \mathrm{mL}) /$ streptomycin $(50 \mu \mathrm{g} / \mathrm{mL})$ antibiotics at $25^{\circ} \mathrm{C}$.

For the aluminum detection experiments, the $\mathrm{S} 2$ cells were treated with $\mathrm{Al}^{3+}$-containing culture medium for $30 \mathrm{~min}$, and then washed with PBS buffer three times, followed by the incubation with Al-II probe-containing medium for $30 \mathrm{~min}$ and additional PBS wash three times. Finally, the fluorescent signals indicating $\mathrm{Al}^{3+}$ ions in these cells were observed under the confocal fluorescence microscope. All steps were carried out at room temperature.

\section{5. $\mathrm{Al}^{3+}$ Detection in Malpighian Tubules}

We chose the Drosophila larval Malpighian tubules as the in vivo organ system to perform the $\mathrm{Al}^{3+}$ detection experiments using the Al-II probe.

Drosophila larvae at third instar stage were fed with fly food containing $\mathrm{Al}^{3+}$ for $30 \mathrm{~min}$. Then the Malpighian tubules were dissected out from larval bodies, washed with PBS buffer, and further treated with Al-II probe for another 30 min followed by another round of PBS wash. Eventually, the Malpighian tubules were observed under the confocal fluorescence microscope. All steps were carried out at room temperature.

\subsection{Confocal Fluorescence Imaging}

Fluorescence imaging was acquired using a Nikon Ti laser scanning confocal fluorescence microscope with a laser $\left(\lambda_{\mathrm{ex}}=402 \mathrm{~nm}\right)$. The emission wavelength range was $500-600 \mathrm{~nm}$. The images were captured under 60x oil lens (cells) or 20x lens (Malpighian tubules) with the pinhole size $71.5 \mu \mathrm{m}$ and Si PMT HV 147.

The fluorescence intensity in cells was measured using the software ImageJ with the threshold (Triangle mode) adjustment. The fluorescence intensity in Drosophila Malpighian tubules was measured using the software ImageJ, then was normalized by the value of control group. The statistical significance was evaluated with Student's t-test.

\section{Results and Discussion}

The desired fluorescent probe Al-II shown in Scheme 1 was synthesized as described above and characterized by LC-MS (Figure S1), ${ }^{1} \mathrm{H}$ NMR (Figure S2) and ${ }^{13} \mathrm{C}$ NMR (Figure S3).<smiles>CC(=O)N/N=C/c1cc(O)ccc1O</smiles>

(E)-N'-(2,5-dihydroxybenzylidene)acetohydrazide<smiles>CC(=O)N/N=C\c1cc(O)ccc1O</smiles>

(Z)-N'-(2,5-dihydroxybenzylidene)acetohydrazide

Scheme 1. Molecular structure of the Al-II probe.

\subsection{Fluorescence Spectra of Detecting $A l^{3+}$}

The reaction time on the binding process of the probe with $\mathrm{Al}^{3+}$ was firstly studied. As shown in Figure 1a, there was obvious red-shift emission and dramatic intensity increase after addition of $\mathrm{Al}^{3+}$ in $5 \mathrm{~min}$ and the intensity reached to a stable value in $10 \mathrm{~min}$. So, in the following studies, we pre-incubated probe-metal ions for $15 \mathrm{~min}$ before testing. The kinetic constant was estimated to be $0.0036 \mu \mathrm{M}^{-1} \mathrm{~min}^{-1}$ based on the linear portion of increase on fluorescent intensity at $500 \mathrm{~nm}$. 
(a)

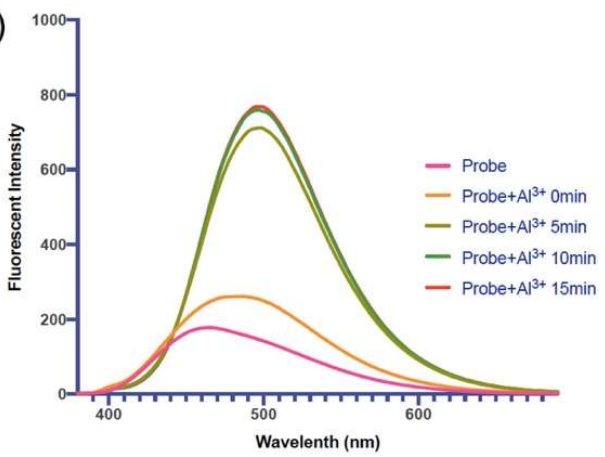

(b)

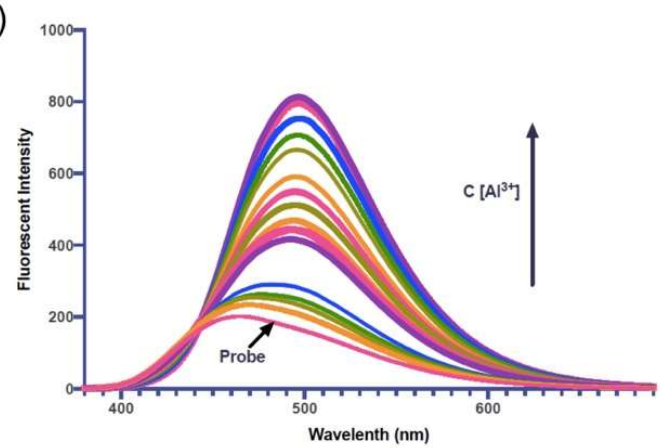

Figure 1. Fluorescent spectra of Al-II probe with $\mathrm{Al}^{3+}$. (a) Fluorescent spectra of Al-II probe $(10 \mu \mathrm{M})$ with $\mathrm{Al}^{3+}(50 \mu \mathrm{M})$ after incubation for $0 \mathrm{~min}, 5 \mathrm{~min}, 10 \mathrm{~min}$ and $15 \mathrm{~min}$. (b) Fluorescent spectra of Al-II probe $(10 \mu \mathrm{M})$ with titration of increased concentration of $\mathrm{Al}^{3+}(1 \mu \mathrm{M}$ to $50 \mu \mathrm{M})$.

Then we performed a detailed investigation on the Al-II probe recognition of $\mathrm{Al}^{3+}$. As shown in Figure $1 \mathrm{~b}$, the fluorescence intensity of Al-II probe $(10 \mu \mathrm{M})$ in aqueous solution at $465 \mathrm{~nm}$ was dramatically increased with the obvious emission red shift to $500 \mathrm{~nm}$ upon addition of $\mathrm{Al}^{3+}$. The changes of the emission intensities became constant when the amount of $\mathrm{Al}^{3+}$ added reached to 5.0 equiv. $(50 \mu \mathrm{M})$.

As the emission of Al-II probe itself has spectra contribution to the spectra of probe- $\mathrm{Al}^{3+}$, so the spectra of Al-II probe were taken as the background signal and was deducted from probe- $\mathrm{Al}^{3+}$ spectra. The relative fluorescent intensity was used for future analysis. The same trend was seen after background deduction (Figure S4). After one-site specific binding analysis, the binding constant of Al-II probe with $\mathrm{Al}^{3+}$ was $10.8 \mu \mathrm{M}$ (Figure S5).

\subsection{Selectivity Over Metal Ions}

The selectivity of Al-II probe as a fluorescent chemo-sensor for the detection of $\mathrm{Al}^{3+}$ among a wide range of environmentally and physiologically active metal ions was investigated by examining the fluorescence of solutions containing Al-II probe and the metal ions in distilled water. As shown in Figure 2a, when 10 equiv. of various metal ions $\left(\mathrm{Al}^{3+}, \mathrm{Li}^{+}, \mathrm{Na}^{+}, \mathrm{Mg}^{2+}, \mathrm{K}^{+}, \mathrm{Ca}^{2+}, \mathrm{Cr}^{3+}, \mathrm{Mn}^{2+}, \mathrm{Fe}^{2+}\right.$, $\mathrm{Fe}^{3+}, \mathrm{Ni}^{2+}, \mathrm{Cu}^{2+}, \mathrm{Zn}^{2+}, \mathrm{Ga}^{3+}, \mathrm{Ba}^{2+}, \mathrm{Gd}^{2+}$, and $\left.\mathrm{Er}^{3+}\right)$ were added to the Al-II probe solution $(10 \mu \mathrm{M})$, $\mathrm{Al}^{3+}$ produced a strong green fluorescence under excitation at $365 \mathrm{~nm}$, whereas other metal ions made no obvious fluorescence.

To more accurately explore the selectivity of probe Al-II over various metal ions, the fluorescence spectra of probe was measured (Figure $2 \mathrm{~b}, \mathrm{c}$ ). In the presence of $\mathrm{Al}^{3+}$, the fluorescence intensity of Al-II probe showed a large enhancement along with a red-shifted emission. In the cases of other metal ions, such as $\mathrm{K}^{+}, \mathrm{Na}^{+}, \mathrm{Mg}^{2+}, \mathrm{Mn}^{2+}, \mathrm{Zn}^{2+}, \mathrm{Ba}^{2+}, \mathrm{Ca}^{2+}, \mathrm{Cr}^{3+}, \mathrm{Fe}^{2+}$ and $\mathrm{Gd}^{2+}$, there were no apparent changes in the fluorescence spectrum of Al-II probe (Figure $2 \mathrm{~b}$ ). Among these various metal ions, $\mathrm{Ga}^{3+}$ also showed an emission red shift, but its intensity was much lower in comparison with $\mathrm{Al}^{3+}$ (Figure $2 \mathrm{~b}$ ). Several metal ions such as $\mathrm{Ni}^{2+}, \mathrm{Er}^{3+}, \mathrm{Cu}^{2+}$ and $\mathrm{Fe}^{3+}$, quenched the emission intensity (Figure 2c), which might be attributed to their intrinsic quenching nature. These results indicated a highly selective ability for probe $\mathrm{Al}-\mathrm{II}$ to detect $\mathrm{Al}^{3+}$ ions.

To further investigate the binding affinity of Al-II probe with $\mathrm{Al}^{3+}$ in the presence of various competing metal ions, Al-II probe was incubated with 5 equiv. of $\mathrm{Al}^{3+}$ in the presence of 5 equiv. of other metal ions. There was little interference for the detection of $\mathrm{Al}^{3+}$ in the presence of $\mathrm{K}^{+}, \mathrm{Na}^{+}$, $\mathrm{Mg}^{2+}, \mathrm{Mn}^{2+}, \mathrm{Zn}^{2+}, \mathrm{Ni}^{2+}, \mathrm{Ba}^{2+}, \mathrm{Ca}^{2+}, \mathrm{Cr}^{3+}, \mathrm{Er}^{3+}, \mathrm{Fe}^{2+}$ and $\mathrm{Gd}^{2+}$ (Figure 3, Figure S6). The $\mathrm{Ga}^{3+}$ ion did have weak competition effect for the $\mathrm{Al}-\mathrm{II}-\mathrm{Al}^{3+}$ binding, while $\mathrm{Cu}^{2+}$ and $\mathrm{Fe}^{3+}$ ions have strong quench effects for the fluorescence of probe Al-II with $\mathrm{Al}^{3+}$. 
(a)
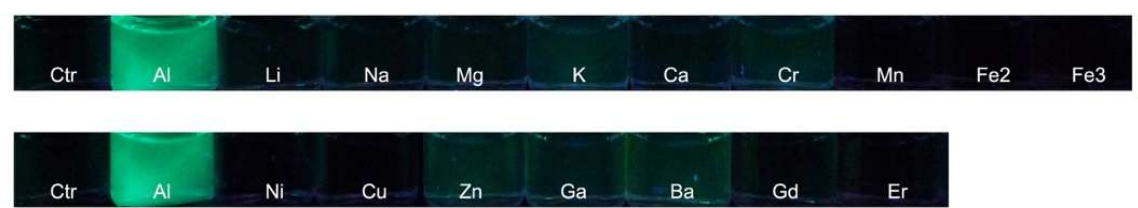

(b)

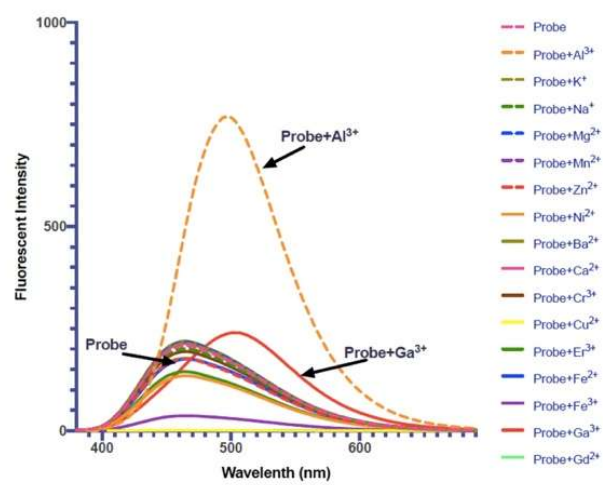

(c)

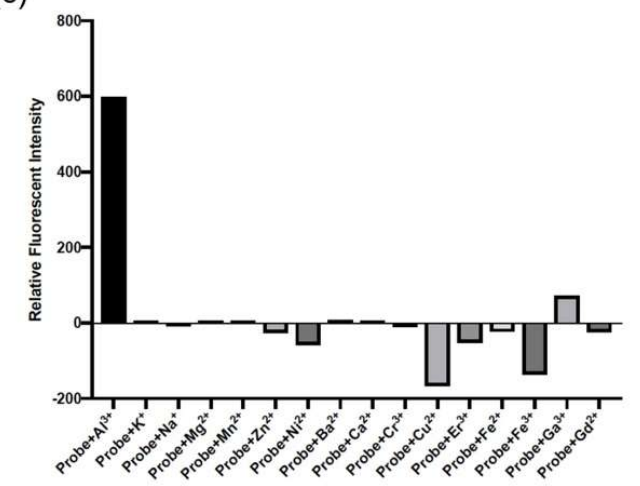

Figure 2. Fluorescence response of the probe Al-II to different metal ions. (a) Changes in the fluorescence of probe $\mathrm{Al}-\mathrm{II}(10 \mu \mathrm{M})$ upon addition of various metal ions (10 equiv.) under excitation at $365 \mathrm{~nm}$. (b) Fluorescent spectra of Al-II probe $(10 \mu \mathrm{M})$ in the presence of $\mathrm{Al}^{3+}(50 \mu \mathrm{M})$ and various metal ions $(50$ $\mu \mathrm{M})$. (c) Relative fluorescent intensity of $\mathrm{Al}-\mathrm{II}$ probe in the presence of $\mathrm{Al}^{3+}$ and various metal ions $\left(\lambda_{\mathrm{ex}}\right.$ $\left.350 \mathrm{~nm}, \lambda_{\mathrm{em}} 500 \mathrm{~nm}\right)$.

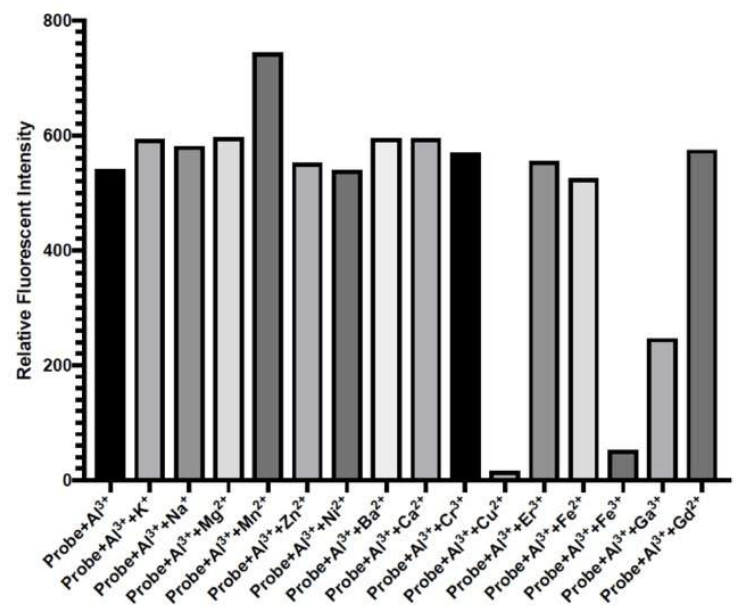

Figure 3. Relative fluorescent intensity of Al-II probe $(10 \mu \mathrm{M})$ upon addition of $\mathrm{Al}^{3+}(50 \mu \mathrm{M})$ in the presence of various metal ions $(50 \mu \mathrm{M})$ in aqueous solution $\left(\lambda_{\mathrm{ex}} 350 \mathrm{~nm}, \lambda_{\mathrm{em}} 500 \mathrm{~nm}\right)$.

\subsection{Detection Range}

The detection limit was calculated based on the fluorescence titration of the probe Al-II. A good linear relationship between the $\mathrm{Al}-\mathrm{II}$ fluorescence intensity and $\mathrm{Al}^{3+}$ concentration could be obtained in the range from 1 to $5 \mu \mathrm{M}(\mathrm{R}=0.9947)$. The detection limit was calculated with the equation: Detection limit $=3^{*} \mathrm{y}$-intercept/slope (as shown in Figure 4), and it was measured to be $0.66 \mu \mathrm{m}$. 


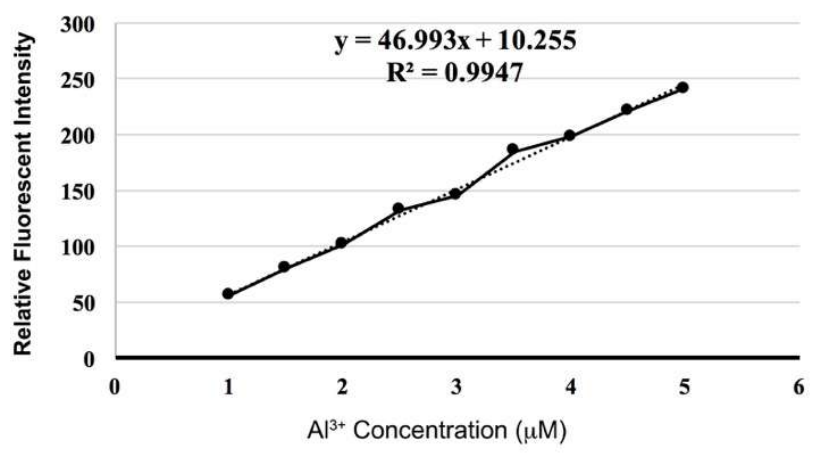

Figure 4. Relative fluorescent intensity of Al-II probe $(10 \mu \mathrm{M})$ upon addition of $\mathrm{Al}^{3+}$ (1 to $\left.5 \mu \mathrm{M}\right)\left(\lambda_{\mathrm{ex}}\right.$ $\left.350 \mathrm{~nm}, \lambda_{\mathrm{em}} 500 \mathrm{~nm}\right)$.

\subsection{Job's Plot}

The stoichiometry between the Al-II probe and $\mathrm{Al}^{3+}$ was validated by Job's plot. The fluorescence emission intensity was measured by changing the molar fraction of $\mathrm{Al}^{3+}$ (the total concentration was $10 \mu \mathrm{M})$ (Figure S7). As shown in Figure 5, the fluorescence emission intensity indicated a maximum at a molar fraction of about 0.5 , exhibiting a $1: 1$ stoichiometry of the probe- $\mathrm{Al}^{3+}$ complex.

(a)

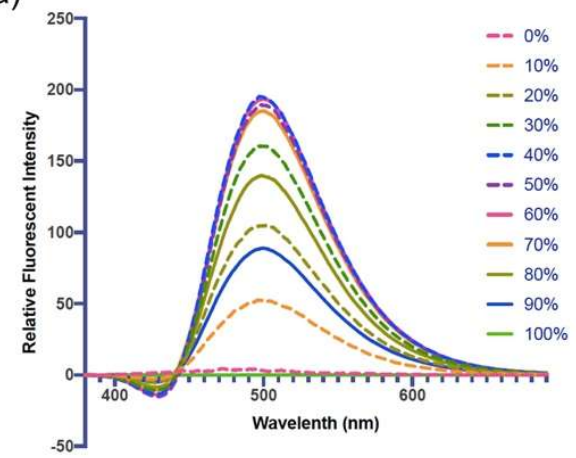

(b)

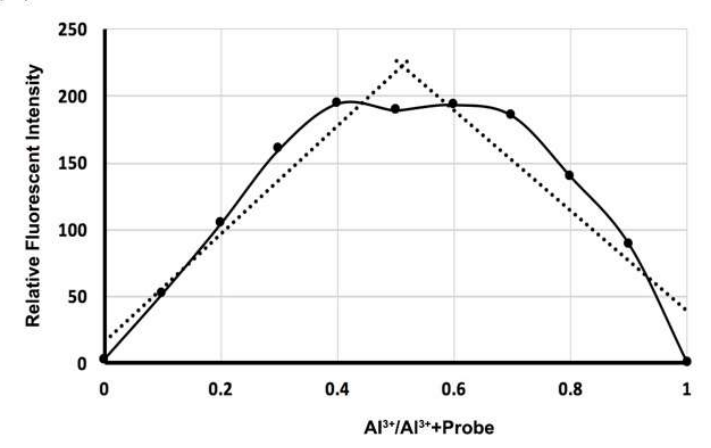

Figure 5. The stoichiometry between the Al-II probe and $\mathrm{Al}^{3+}$. (a) Relative fluorescent spectra of different combination system of $\mathrm{Al}^{3+}$ and $\mathrm{Al}-\mathrm{II}$ probe (with $\mathrm{Al}^{3+}$ from $0 \%$ to $100 \%$, the total concentration is $10 \mu \mathrm{M})$. (b) Job's plot for determining the stoichiometric complexation of Al-II probe with $\mathrm{Al}^{3+}$ in aqueous solution. The fluorescence at $500 \mathrm{~nm}$ emission was plotted.

\subsection{UV-vis Spectra}

To elucidate the binding mode of the probe and $\mathrm{Al}^{3+}$, we have performed the UV-vis spectra test. As shown in Figure 6, probe Al-II $(25 \mu \mathrm{M})$ has two absorbance peaks at $280 \mathrm{~nm}$ and $340 \mathrm{~nm}$. As the $\mathrm{Al}^{3+}$ concentration was increasing, the absorption peaks at $280 \mathrm{~nm}$ and $340 \mathrm{~nm}$ were gradually red-shifted to $290 \mathrm{~nm}$ and $370 \mathrm{~nm}$. The intensity of new absorption peaks at $290 \mathrm{~nm}$ and $370 \mathrm{~nm}$ were increased upon addition of increased concentration of $\mathrm{Al}^{3+}$ and the intensity reached to stable value when the concentration of $\mathrm{Al}^{3+}$ added was $150 \mu \mathrm{M}$ (6 equiv.). The large spectral bathochromic shift indicated the deprotonation, as a consequence of $\mathrm{Al}^{3+}$ binding to phenol. 


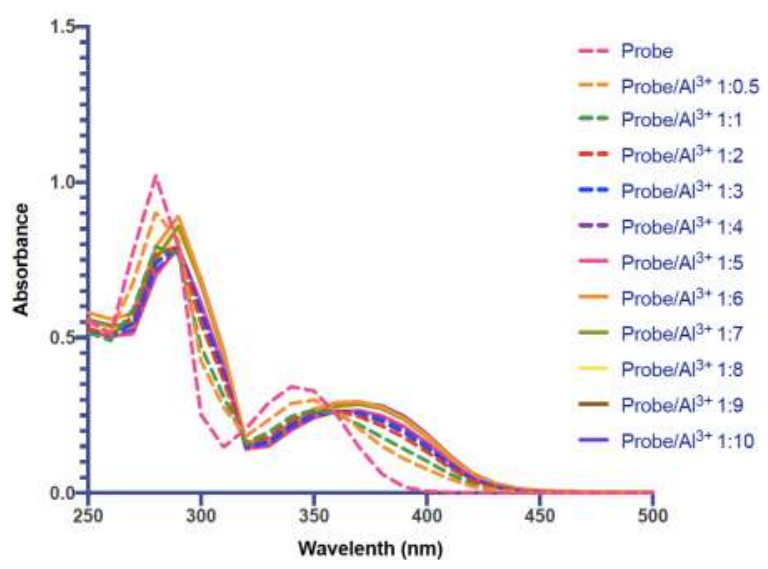

Figure 6. Absorbance spectra of Probe Al-II $(25 \mu \mathrm{M})$ with titration of increased concentration of $\mathrm{Al}^{3+}$ $(1.5 \mu \mathrm{M}$ to $250 \mu \mathrm{M})$.

We also measured the absorbance spectra of probe in the presence of $\mathrm{Cu}^{2+}$ and $\mathrm{Fe}^{3+}$ (Figure S8). Compared with $\mathrm{Al}^{3+}, \mathrm{Cu}^{2+}$ gave a larger red-shifted peak around $410 \mathrm{~nm}$ and $\mathrm{Fe}^{3+}$ has a very broad spectrum, which is consistent with the presence of ligand-to-metal charge-transfer (LMCT) in case of $\mathrm{Cu}^{2+}$ and $\mathrm{Fe}^{3+}$.

\subsection{Application of Probe Al-II for Aluminum Detection in Living Cells}

We examined the ability of Al-II probe for the detection of intracellular $\mathrm{Al}^{3+}$ in living biological systems under a confocal laser scanning microscopy. Drosophila S2 cells were incubated in the culture medium containing $\mathrm{Al}^{3+}(100 \mathrm{mM})$ for $30 \mathrm{~min}$ at room temperature. Then the $\mathrm{Al}^{3+}$ medium was removed and cells were washed with PBS buffer solution three times. The cells were further treated with Al-II probe $(500 \mu \mathrm{M})$ for $30 \mathrm{~min}$ at room temperature, followed by PBS washing, three times, and imaging under confocal fluorescence microscope (Figure 7). As a negative control, the cells without $\mathrm{Al}^{3+}$ treatment showed no fluorescence (Figure 7a,b). The S2 cells with $\mathrm{Al}^{3+}$ treatment exhibited a strong green fluorescence (Figure 7c). Moreover, the cell morphology remained in a good condition after the addition of Al-II probe, indicating low toxicity of the probe. The Al-II probe can also be applied to the fixed cells, giving the similar results. These data demonstrated that the Al-II probe is cell membrane permeable and is useful for the imaging of intracellular $\mathrm{Al}^{3+}$ ions in living cells and fixed cells as well.
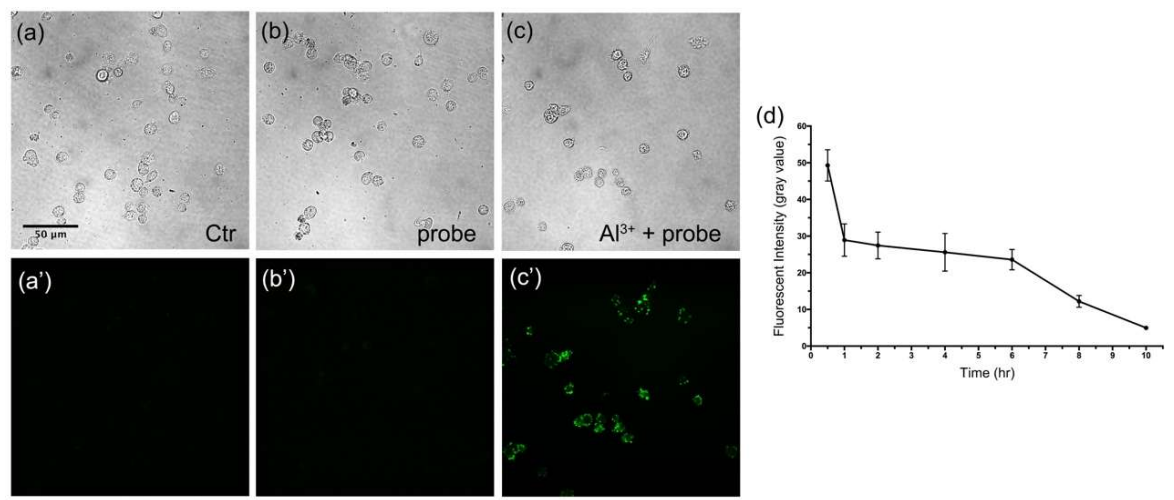

Figure 7. Detection of $\mathrm{Al}^{3+}$ in Drosophila S2 cells using the Al-II probe upon excitation at $402 \mathrm{~nm}$. $\left(\mathbf{a}, \mathbf{a}^{\prime}\right)$ The cells without any treatment. $\left(\mathbf{b}, \mathbf{b}^{\prime}\right)$ The cells incubated with the probe $(500 \mu \mathrm{M}, 30 \mathrm{~min})$. $\left(\mathbf{c}, \mathbf{c}^{\prime}\right)$ The cells sequentially incubated with $\mathrm{Al}^{3+}(100 \mathrm{mM}, 30 \mathrm{~min})$ and the probe $(500 \mu \mathrm{M}, 30 \mathrm{~min})$. The fluorescence images $\left(\mathbf{a}^{\prime}, \mathbf{c}^{\prime}\right)$ are corresponding to the bright field images $(\mathbf{a}, \mathbf{c})$, respectively. The horizontal bar in panel a represents $50 \mu \mathrm{m}$ and applies for all images of this figure. (d) The measurement of the fluorescent intensity in Al-probe-treated cells. 
In addition, we measured the retention time of the Al-probe fluorescence inside cells (Figure 7d). As shown, the fluorescence intensity of Al-probe was quickly decreased after $30 \mathrm{~min}$ and maintained at a half level from $1 \mathrm{~h}$ to $6 \mathrm{~h}$, then gradually decreased until nearly invisible at $10 \mathrm{~h}$ time point.

\subsection{Imaging of $\mathrm{Al}^{3+}$ in Drosophila Malpighian Tubules Using Al-II Probe}

The most attractive application for Al-II probe is sensing $\mathrm{Al}^{3+}$ in living organisms [31]. We chose the Drosophila Malpighian tubules as the model to detect $\mathrm{Al}^{3+}$ ions using the Al-II probe in living biological systems. The Malpighian tubule is the main organ to process metal ions in Drosophila, functionally analogous to mammalian kidney, and has recently become an important model organism for the study of metal ion transportation [32]. We first fed the 3rd instar larvae with $\mathrm{Al}^{3+}(100 \mathrm{mM})$ for $30 \mathrm{~min}$ and dissected the Malpighian tubules from larval bodies and washed them with PBS buffer. Then, we treated the Malpighian tubules with the Al-II probe $(1 \mathrm{mM})$ for $30 \mathrm{~min}$ at room temperature, followed by image capture using confocal fluorescence microscope (Figure 8). As shown, compared with control sample without treatments, the Malpighian tubules with $\mathrm{Al}^{3+}$ and probe treatments showed strong fluorescence. These evidence indicated that the Al-II probe can be used for monitoring the distribution of $\mathrm{Al}^{3+}$ in living bodies.
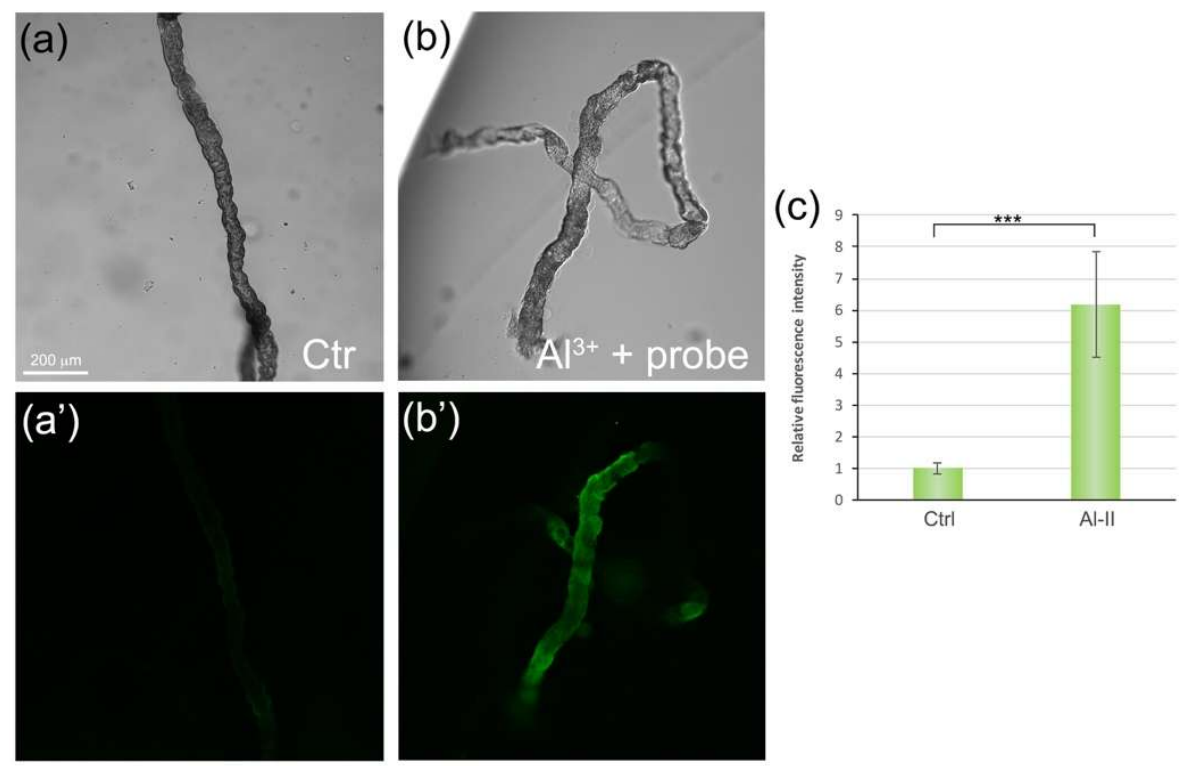

Figure 8. Detection of $\mathrm{Al}^{3+}$ in Drosophila Malpighian tubules using the Al-II probe upon excitation at $402 \mathrm{~nm}$. (a) A bright field image of Malpighian tubules without treatments. (a') The corresponding fluorescence image of Malpighian tubules in panel a. (b) A bright field image of Malpighian tubules treated with $\mathrm{Al}^{3+}(100 \mathrm{mM}, 30 \mathrm{~min})$ and probe $(1 \mathrm{mM}, 30 \mathrm{~min})$. ( $\left.\mathbf{b}^{\prime}\right)$ The corresponding fluorescence image of Malpighian tubules in panel b. The horizontal bar in panel a represents $200 \mu \mathrm{m}$ and applies for all four images of this figure. (c) The quantification of relative fluorescence intensity of Al-II probe in Malpighian tubules. $n>=3 .{ }^{*}$ represents $p<0.05,{ }^{* *}$ represents $p<0.005,{ }^{* * *}$ represents $p<0.0005$.

\section{Conclusions}

In summary, we have designed and successfully synthesized a fluorescent probe $\mathrm{Al}-\mathrm{II}$ to detect $\mathrm{Al}^{3+}$ ions. The probe revealed high selectivity and strong fluorescence to $\mathrm{Al}^{3+}$. Moreover, we successfully detected the intracellular $\mathrm{Al}^{3+}$ in the living cells as well as Drosophila Malpighian tubules utilizing the Al-II probe. Therefore, the Al-II probe not only is able to detect $\mathrm{Al}^{3+}$ ions in aqueous solution, but also serves as a potentially useful tool for monitoring the intracellular distribution of $\mathrm{Al}^{3+}$ in biological systems. 
Supplementary Materials: The following are available online at http://www.mdpi.com/1424-8220/19/11/2423/s1: Figure S1: HPLC spectrum of compound Al-II. Figure S2: ${ }^{1} \mathrm{H}$ NMR spectrum of compound Al-II. Figure S3: ${ }^{13} \mathrm{C}$ NMR spectrum of compound Al-II. Figure S4: Fluorescent spectra of Al-II probe $(10 \mu \mathrm{M})$ with titration of increased concentration of $\mathrm{Al}^{3+}(1 \mu \mathrm{M}$ to $50 \mu \mathrm{M})$ after spectra subtraction of Al-II probe. Figure S5: Nonlinear one-site specific binding curve with relative fluorescent intensity after $\mathrm{Al}^{3+}(1 \mu \mathrm{M}$ to $50 \mu \mathrm{M})$ titration $\left(\mathrm{R}^{2}=0.9816\right.$, $\mathrm{Kd}=10.8)$. Figure $\mathrm{S6}$ : Fluorescence response of the probe to $\mathrm{Al}^{3+}$ in the presence of higher concentration of $\mathrm{Na}^{+}$ and $\mathrm{K}^{+}$. Figure S7: Original fluorescent spectra of different combination system of $\mathrm{Al}^{3+}$ and probe (with $\mathrm{Al}^{3+}$ from $0 \%$ to $100 \%$, the total concentration is $10 \mu \mathrm{M})$. Figure S8: Absorbance spectra of Probe Al-II $(25 \mu \mathrm{M})$ with $\mathrm{Al}^{3+}, \mathrm{Cu}^{2+}$ or $\mathrm{Fe}^{3+}(250 \mu \mathrm{M})$.

Author Contributions: Conceptualization, L.Z.; data curation, L.Z.; formal analysis, J.Y. and H.W.; funding acquisition, Y.S.; investigation, L.W. and J.Y.; methodology, L.W. and J.Y.; project administration, L.Z.; supervision, L.Z.; validation, C.R. and Y.S.; writing-original draft, L.W., J.Y. and H.W.; writing-review \& editing, Y.S.

Funding: This work was supported by the National Natural Science Foundation of China (31701274), the Fundamental Research Funds for the Central Universities (201612010 and 201822016).

Conflicts of Interest: The authors declare no conflict of interest.

\section{References}

1. Krewski, D.; Yokel, R.A.; Nieboer, E.; Borchelt, D.; Cohen, J.; Harry, J.; Kacew, S.; Lindsay, J.; Mahfouz, A.M.; Rondeau, V. Human health risk assessment for aluminium, aluminium oxide, and aluminium hydroxide. $J$. Toxicol. Environ. Health B Crit. Rev. 2007, 10, 1-269. [CrossRef] [PubMed]

2. Inostroza-Blancheteau, C.; Rengel, Z.; Alberdi, M.; de la Luz Mora, M.; Aquea, F.; Arce-Johnson, P.; Reyes-Diaz, M. Molecular and physiological strategies to increase aluminum resistance in plants. Mol. Biol. Rep. 2012, 39, 2069-2079. [CrossRef] [PubMed]

3. Mohseni, H.K.; Chettle, D.R. A History of In Vivo Neutron Activation Analysis in Measurement of Aluminum in Human Subjects. J. Alzheimers. Dis. 2016, 50, 913-926. [CrossRef] [PubMed]

4. Perl, D.P.; Brody, A.R. Alzheimer's disease: X-ray spectrometric evidence of aluminum accumulation in neurofibrillary tangle-bearing neurons. Science 1980, 208, 297-299. [CrossRef]

5. Tavakoli, O.; Yoshida, H. Effective recovery of harmful metal ions from squid wastes using subcritical and supercritical water treatments. Environ. Sci. Technol. 2005, 39, 2357-2363. [CrossRef]

6. Lou, Z.; Li, P.; Song, P.; Han, K. Ratiometric fluorescence imaging of cellular hypochlorous acid based on heptamethine cyanine dyes. Analyst 2013, 138, 6291-6295. [CrossRef]

7. Blackburn, A.C.; Doe, W.F.; Buffinton, G.D. Protein carbonyl formation on mucosal proteins in vitro and in dextran sulfate-induced colitis. Free Radic. Biol. Med. 1999, 27, 262-270. [CrossRef]

8. Soroka, K.; Vithanage, R.S.; Phillips, D.A.; Walker, B.; Dasgupta, P.K. Fluorescence properties of metal complexes of 8-Hydroxyquinoline-5-sulfonic acid and chromatographic applications. Anal. Chem. 1987, 59, 629-636. [CrossRef]

9. Valeur, B.; Leray, I. Design principles of fluorescent molecular sensors for cation recognition. Coord. Chem. Rev. 2000, 205, 3-40. [CrossRef]

10. Wang, Y.; Hou, L.J.; Wu, Y.B.; Shi, L.L.; Shang, Z.B.; Jin, W.J. Alizarin Complexone as a highly selective ratiometric fluorescent probe for $\mathrm{Al} 3+$ detection in semi-aqueous solution. J. Photoch. Photobio. A 2014, 281, 40-46. [CrossRef]

11. Li, M.X.; Zhang, X.; Fan, Y.H.; Bi, C.F. A novel fluorescent probe based on rhodamine hydrazone derivatives bearing a thiophene group for $\mathrm{Al}^{3+}$. Luminescence 2016, 31, 851-855. [CrossRef]

12. Jiang, Y.; Sun, L.L.; Ren, G.Z.; Niu, X.; Hu, W.Z.; Hu, Z.Q. A New Fluorescence Turn-On Probe for Aluminum(III) with High Selectivity and Sensitivity, and its Application to Bioimaging. ChemistryOpen 2015, 4, 378-382. [CrossRef] [PubMed]

13. Xiao, H.; Chen, K.; Jiang, N.; Cui, D.; Yin, G.; Wang, J.; Wang, R. A highly selective turn-on fluorescent probe for $\mathrm{Al}(\mathrm{III})$ based on coumarin and its application in vivo. Analyst 2014, 139, 1980-1986. [CrossRef]

14. Peng, H.; Shen, K.; Mao, S.; Shi, X.; Xu, Y.; Aderinto, S.O.; Wu, H. A Highly Selective and Sensitive Fluorescent Turn-on Probe for $\mathrm{Al}^{3+}$ Based on Naphthalimide Schiff Base. J. Fluoresc. 2017, 27, 1191-1200. [CrossRef]

15. Ahmed, M.; Faisal, M.; Ihsan, A.; Naseer, M.M. Fluorescent organic nanoparticles (FONs) as convenient probes for metal ion detection in aqueous medium. Analyst 2019, 144, 2480-2497. [CrossRef] [PubMed] 
16. Hsieh, W.H.; Wan, C.-F.; Liao, D.-J.; Wu, A.-T. A turn-on Schiff base fluorescence sensor for zinc ion. Tetrahedron Lett. 2012, 53, 5848-5851. [CrossRef]

17. Jia, T.-J.; Cao, W.; Zheng, X.-J.; Jin, L.-P. A turn-on chemosensor based on naphthol-triazole for Al(III) and its application in bioimaging. Tetrahedron Lett. 2013, 54, 3471-3474. [CrossRef]

18. Chen, Y.; Jiang, J. Decoding the phosphorylation code in Hedgehog signal transduction. Cell Res. 2013, 23, 186-200. [CrossRef] [PubMed]

19. In, B.; Hwang, G.W.; Lee, K.H. Highly sensitive and selective detection of $\mathrm{Al}(\mathrm{III})$ ions in aqueous buffered solution with fluorescent peptide-based sensor. Bioorg. Med. Chem. Lett. 2016, 26, 4477-4482. [CrossRef]

20. Li, C.-Y.; Zhou, Y.; Li, Y.-F.; Zou, C.-X.; Kong, X.-F. Efficient FRET-based colorimetric and ratiometric fluorescent chemosensor for $\mathrm{Al}^{3+}$ in living cells. Sens. Actuators, B 2013, 186, 360-366. [CrossRef]

21. Ezhumalai, D.; Mathivanan, I.; Chinnadurai, A. Turn on macrocyclic chemosensor for $\mathrm{Al}(3+)$ ion with facile synthesis and application in live cell imaging. Spectrochim. Acta A Mol. Biomol. Spectrosc. 2018, 199, 209-219. [CrossRef]

22. Li, Z.; Liu, C.; Wang, J.; Wang, S.; Xiao, L.; Jing, X. A selective diaminomaleonitrile-based dual channel emissive probe for $\mathrm{Al}^{3+}$ and its application in living cell imaging. Spectrochim. Acta A Mol. Biomol. Spectrosc. 2019, 212, 349-355. [CrossRef]

23. Zhou, F.; Wang, H.; Liu, P.; Hu, Q.; Wang, Y.; Liu, C.; Hu, J. A highly selective and sensitive turn-on probe for aluminum(III) based on quinoline Schiff's base and its cell imaging. Spectrochim. Acta A Mol. Biomol. Spectrosc. 2018, 190, 104-110. [CrossRef]

24. Gupta, S.R.; Singh, P.; Koch, B.; Singh, V.P. A water soluble, highly sensitive and selective fluorescent probe for $\mathrm{Al}^{3+}$ ions and its application in live cell imaging. J. Photochem. Photobiol. A 2017, 348, 246-254. [CrossRef]

25. Balamurugan, G.; Velmathi, S.; Thirumalaivasan, N.; Wu, S.P. New phenazine based AIE probes for selective detection of aluminium(iii) ions in presence of other trivalent metal ions in living cells. Analyst 2017, 142, 4721-4726. [CrossRef]

26. Ding, W.-H.; Wang, D.; Zheng, X.-J.; Ding, W.-J.; Zheng, J.-Q.; Mu, W.-H.; Cao, W.; Jin, L.-P. A turn-on fluorescence chemosensor for $\mathrm{Al}^{3+}, \mathrm{F}^{-}$and $\mathrm{CN}^{-}$ions, and its application in cell imaging. Sens. Actuators, $B$ 2015, 209, 359-367. [CrossRef]

27. Saini, A.K.; Sharma, V.; Mathur, P.; Shaikh, M.M. The development of fluorescence turn-on probe for Al(III) sensing and live cell nucleus-nucleoli staining. Sci. Rep. 2016, 6, 34807. [CrossRef]

28. Liu, Y.; Bi, A.; Gao, T.; Cao, X.; Gao, F.; Rong, P.; Wang, W.; Zeng, W. A novel self-assembled nanoprobe for the detection of aluminum ions in real water samples and living cells. Talanta 2019, 194, 38-45. [CrossRef]

29. Li, C.L.; Lu, P.H.; Fu, S.F.; Wu, A.T. A Highly Selective and Sensitive Fluorescent Chemosensor for Detecting $\mathrm{Al}^{3+}$ Ion in Aqueous Solution and Plant Systems. Sensors 2019, 19. [CrossRef]

30. Tian, H.; Qiao, X.; Zhang, Z.L.; Xie, C.Z.; Li, Q.Z.; Xu, J.Y. A high performance 2-hydroxynaphthalene Schiff base fluorescent chemosensor for $\mathrm{Al}^{3+}$ and its applications in imaging of living cells and zebrafish in vivo. Spectrochim. Acta A Mol. Biomol. Spectrosc. 2019, 207, 31-38. [CrossRef]

31. Devirgiliis, C.; Zalewski, P.D.; Perozzi, G.; Murgia, C. Zinc fluxes and zinc transporter genes in chronic diseases. Mutat. Res. 2007, 622, 84-93. [CrossRef]

32. Xiao, G.; Zhou, B. What can flies tell us about zinc homeostasis? Arch. Biochem. Biophys. 2016, 611, $134-141$. [CrossRef]

(C) 2019 by the authors. Licensee MDPI, Basel, Switzerland. This article is an open access article distributed under the terms and conditions of the Creative Commons Attribution (CC BY) license (http://creativecommons.org/licenses/by/4.0/). 